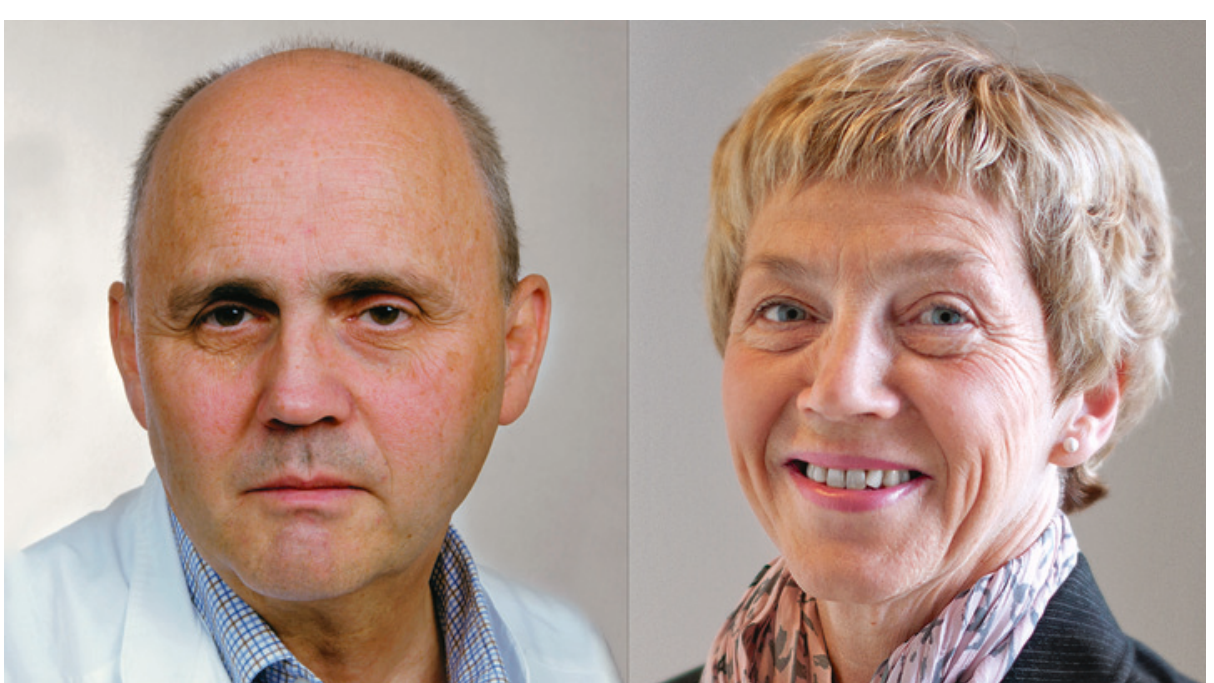

Odd Monge (foto Ann Sissel Herdlevær) og Kirsten Sundby Hall (foto Per Marius Didriksen), de to norske artikkelforfatterne

\title{
Fremskritt i sarkombehandling
}

\author{
Tre års adjuvant behandling med imatinib etter radikalkirurgi for gastro- \\ intestinal stromal tumor er bedre enn ett års behandling. Det viser en \\ skandinavisk-tysk fase 3-studie.
}

400 pasienter med KIT(CD 117)-positiv gastrointestinal stromal tumor og med over $50 \%$ risiko for residiv etter radikaloperasjon ble randomisert til enten tre eller ett års behandling med imatinib $400 \mathrm{mg}$ daglig (1). Studien ble gjennomført i regi av den skandinaviske sarkomgruppen i perioden 2004-08. For vurdering av risiko ble NIHklassifikasjonen benyttet.

$92 \%$ av dem som ble behandlet med imatinib i tre år, var i live etter fem år, sammenliknet med $82 \%$ av dem som fikk imatinib i ett år. Andelen som ikke hadde fått residiv etter fem år var henholdsvis $66 \%$ og $48 \%$. Denne forskjellen var statistisk signifikant. Andelen som seponerte imatinib pga. bivirkninger, bl.a. periorbitalt ødem, utmattelse (fatigue), kvalme og kramper, var henholdvis $13 \%$ og 7,5\%.

- Disse resultatene ble første gang presentert ved ASCO-kongressen, verdens største kreftkongress, i juni 2011 og vakte betydelig oppsikt, sier overlege Kirsten Sundby Hall ved Oslo universitetssykehus, Radiumhospitalet. - For første gang kunne vi vise at imatinib ikke bare forlenger tiden til residiv, men også forlenger livet til pasienter i høyrisikogruppen. Imatinib er godkjent for adjuvant behandling $\mathrm{i}$ både USA og Europa, forteller hun.

- Skandinavisk sarkomgruppe følger internasjonale anbefalinger, som er imatinib $400 \mathrm{mg}$ daglig i tre år som standardbehandling. Flere spørsmål står fortsatt ubesvart når det gjelder adjuvant behandling, bl.a. optimal dose, behandlingslengde og pa- sientseleksjon. Ved visse genmutasjoner i tumor anbefales ikke adjuvant imatinibbehandling. Derfor er mutasjonsanalyser gjort ved spesiallaboratorier påkrevd. Man vet heller ikke nok om hvilken betydning adjuvant behandling kan ha for utvikling av sekundær resistens, selv om erfaringen er at pasienter som får metastaser på et senere tidspunkt, har effekt av imatinib. Uansett er resultatene fra studien gledelige og vekker optimisme, sier Sundby Hall.

\section{Forskergruppen}

Skandinavisk sarkomgruppe (SSG) hadde det administrative ansvaret for studien, som var forskerinitiert og ledet av professor Heikki Joensuu ved universitetssykehuset i Helsingfors. Novartis finansierte studien. 24 sentre i Finland, Norge, Sverige og Tyskland deltok. I Norge ble 27 pasienter ved Universitetssykehuset Nord-Norge, St. Olavs hospital, Haukeland universitetssykehus og Oslo universitetssykehus, Radiumhospitalet inkludert. Norske medforfattere var Odd Monge ved Haukeland universitetssykehus og Kirsten Sundby Hall ved Radiumhospitalet, som også var norsk koordinator.

\section{Erlend Hem}

erlend.hem@medisin.uio.no

Tidsskriftet

\section{Litteratur}

1. Joensuu H, Eriksson M, Sundby Hall K et al. One vs three years of adjuvant imatinib for operable gastrointestinal stromal tumor: a randomized trial. JAMA 2012; 307: 1265-72.
Ordforklaringer

Gastrointestinal stromal tumor (GIST): Det hyppigst forekommende sarkom i gastrointestinalkanalen.

Imatinib: En tyrosinkinasehemmer som har revolusjonert behandlingen ved metastatisk gastrointestinal stromal tumor.

NIH-klassifikasjon: National Institutes of Health Consensus Criteria. Tumorstørrelse og antall mitoser benyttes sammen med +/tumorruptur.

\section{ASCO: American Society of Clinical Oncology.}

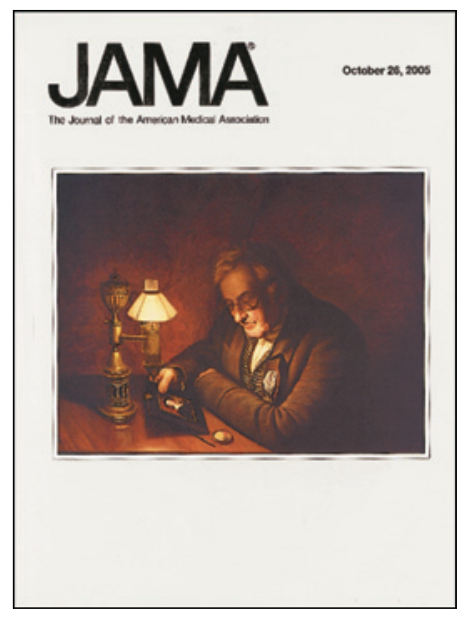

Artikkelen ble publisert 28.3. 2012 i JAMA (www.jama.com), som regnes som en av de «fem store» innen medisinsk publisering ved siden av New England Journal of Medicine, BMJ, Annals of Internal Medicine og The Lancet 